\title{
Extra Classes Effectiveness in Smart Secondary School, Johore, Malaysia
}

\author{
Assoc. Prof. Dr. Asri Selamat (Corresponding author), Assoc. Prof. Dr. Ahmad Esa, Assoc. Prof. Dr. \\ Berhannudin Mohd Salleh \& Dr Ishak Baba \\ University of Tun Hussein Onn Malaysia \\ 86400 Parit Raja, Batu Pahat, Johor, Malaysia \\ Tel: 60-7-453-8559_E-mail: asri@thm.edu.my,ahmad@uthm.edu.my
}

\author{
Received: May 8, $2010 \quad$ Accepted: August 4, $2011 \quad$ Published: January 1, 2012 \\ doi:10.5539/ass.v8n1p111 \\ URL: http://dx.doi.org/10.5539/ass.v8n1p111
}

\begin{abstract}
The purpose of this study was to evaluate extra classes'effectiveness at Smart Secondary School, Johor. This entire research was conducted for about a year using a method called triangualitation which is a combination between quantitative and qualitative method. Six main methods namely survey, questionnaire, interview, observation, documentation checklist and analysis were used to collect data. In questionnaire method, study subject involved 242 respondents constituting teachers who teach in nine of Smart Secondary Schools in Johore while qualitative method involved 10 respondents by interview, 12 aspects observation, 15 aspects checklist and 17 collected documentation which comprises of official document, test material and examination. Respondent sample questionnaire was randomly chosen while interview criteria in interview items had been set by the researcher. Two sets of instruments were carried out in two different schools. Reliability index through pilot study of both instrument sets are from 0.7256 to 0.9165 .Quantitative data to be analysed using Computer Software SPSS Version 10.5 For Windows to get statistic mean and standard deviation. Qualitative data were analyzed using a coding system adapted from Marohaini (2001) research findings indicate that additional classes can improve performance in learning and it is extended by the students'excellence in tests. However, researchers recommended the implementation of intensive counseling classes should be extended to other subjects.
\end{abstract}

Keywords: Extra classes, Smart secondary school

\section{Introduction}

Vision 2020 made our country a comparable industrial nation among other developed countries around the world. The Malaysian society will become a scientific and progressive society, innovative and looking ahead into the future, which in result, produced a society that are advanced in the use of technology, which enable them to contribute to the country. As a step to meet these aspirations, we need to produce a solid workforce that is knowledgeable, independent and skilled.

The field of education develops rapidly in waves of changes which encompasses of philosophical aspect, changes in the system, curriculum, pedagogy, vision and mission in order to keep with the current trends (Rusli, 2002). Recognizing the importance of education in this country, every educator is responsible for shaping the culture of excellence among students, both from secondary schools or higher learning institutions.

Various measures have been planned by schools, parents and students themselves in an effort to enhance the image and status of the school, in addition to providing a positive learning environment. One effort that has been taken is to increase the achievement of excellence in students through extra classes. These extra classes are facilitated by teachers selected among the teachers involved in schools. (Noorwati and Zaharah , 2003).

Parents now are inclined to send their children to tuition centers or obtain the services of personal tutors for their children at home because of the growing need to see their children achieve academic success. Parents are willing to spend a lot of money as long as their children are not left behind in the race to get as many As in exams. However, the enthusiasm of parents and children towards tuition is as if the school teachers are not as effective. Meanwhile, there are many more teachers in schools with the ability that can be used as reference for students. However, the teaching methods of teachers also influence the effectiveness of extra classes of students' academic 
achievement (Mahzan, 2004). This is due to the teaching style that is inconsistent with the learning style of students .Furthermore, teaching students in schools can be misleading and thus interfere with the process of teaching and learning in schools.

In addition, students who go to tuition have the thinking that their problems cannot be resolved fully by teachers in schools because class size is too large and teachers do not have enough time to focus on them, especially to weak students. Therefore, these students turn to tuition teachers for solutions. This is in addition to the workload of teachers which made their job scope not just limited to teaching in class. They have to do clerical work which is not supposed to be their job - they do not have the time to approach students who face problems in education.

This attitude towards schoolteachers can affect students' achievement in subjects in schools. This is because if students have negative attitudes towards their teachers' teaching, it is difficult for them to focus on teaching in these extra classes. When someone is interested then he or she decided to study diligently to achieve success with further facilitate the process of teaching teachers extra classes (Stephens \& Crawley, 1994). For a teacher, the teaching preparations made before entering class is to help remind themselves as teachers are always busy with their duties (Farrant, 1981). According to Abd. Ghafar (2003), to determine the effectiveness of teaching, a lesson plan must be prepared prior to lessons.

So, a student who wants to succeed in study should develop a positive attitude towards what is learned in the classroom or in extra classes. Thinking and having a positive attitude will encourage student's interest in learning. Positive attitudes towards lessons learned can be nurtured and motivated students to take instructive example. A student must also be willing to receive any reprimand from his teacher and tutoring to improve weaknesses. This attitude will indefinitely shape an excellent individual in the future.

Teachers' attitudes play a significant role to produce the effects of teaching to students. This is due to teachers learning to become a role model for their students. In addition to learning from teachers, students also learn about behaviour and language used by their teachers (Dembo, 1977). Attitudes of teachers in principle will affect and determine how teachers' think (Clark and Yinger, 1987). Preparation of teachers, teachers' teaching methods, teachers' attitudes and students' attitude play an important role to the effectiveness of additional classes conducted by teachers in schools for students.

As teachers, they must equip themselves with knowledge. Therefore, teachers should plan more creatively in terms of facilities and resources, plus providing references to teaching and learning activities (T\&L) in order to make the experience more meaningful and perfect. As a teacher, it is important to make decisions that can help all students in the class. Another responsibility is to encourage participation in class so that students will feel that they have responsibility to learn. When students show desire to learn, it will be a motivation to the teachers and proving that their methods produce fruitful results. (Orlich et al. 2001).

\section{Problem Statement}

Actually one of the keys to the success of students' academic achievement is through attending extra classes. Since the implementation of intensive counseling classes to improve students' mathematics performance group is simple, researchers suggest that the implementation of intensive counseling classes should be extended to other subjects such as science and English. Intensive guidance module implementation class can be implemented by the District Education Office and the Department of Education State (Jaafar, et. al).

Effectiveness of tuition towards the achievement of student performance is still a concern. This phenomenon is explained if two students from the same school, attended the same tuition classes, yet both gained different results. However, it cannot be denied that the attitudes, interests and learning styles of different students also affect the effectiveness of additional classes attended by these students.

Government has spent a lot of provisions to develop programs like additional classes in schools to ensure students achieve excellent academic results. Among the programs organized by the government is the Tuition Voucher Scheme (TVS) which cost RM 200 million. This scheme began to be implemented over Malaysia for standard 4-6 students from low-income families. In this scheme, each student who has been identified will receive a coupon worth $\mathrm{rm} 50$ a month to attend tuition classes provided by the school after school hours. These tuition classes are conducted by teachers who are selected by the school (Noorwati and Zaharah, 2003).

The matters set out above are the phenomenon of organized extra classes for less fortunate students. For the more fortunate ones, most of them will pay a lot to attend classes at private tuition centers. Parents are forced to produce a large expense to send their children to tuition centers to ensure that the children receive excellent results in examination (Arshad, 2004). Expenses can sometimes reach up to RM 60 per hour. According to Salleh and Manan (2003)study on existing tuition centers stated that, students will be charged a monthly fee for each 
class attended. Thus, students who take more classes will be charged a higher fee. The subjects offered in tuition centres are depending on the capability of the centre itself, thus, are varied from one centre to another.

There are many students who attend classes at the tuition center or extra classes in school, but its effectiveness against achievement of the performance of students is still a concern. This phenomenon is explained if two students from the same school, attended tuition but get the same results of different examinations. However, it cannot be denied that the attitudes, interests and learning styles of different students also affect the effectiveness of additional classes attended by these students. Studies have been done by Jaafar et al., (2008) of UPSR students have shown the positive effect that there is a significant difference between pre test and post-test showed that there is effective implementation of intensive classes under the guidance of the project Sekolah Angkat Maktab Perguruan project (SAMP). However, for students in secondary school, this was necessary matter given more in-depth study.

There are many factors that influence the effectiveness of student learning for academic achievement, including the teaching methods of teachers (Mahzan, 2004). This is because the teaching style that is not consistent with the learning styles may confuse students and thus interfere with the process of teaching and learning in schools. In such circumstances, students become the next victim and become weak in the subjects involved. So, one alternative to improve the students' learning process is to attend extra classes organized by schools. However, the effectiveness of class followed by the additional students is still a question. Therefore, the study was conducted to examine student's perceptions of the effectiveness of organized extra classes in school.

\section{Study Questions}

1). How is the implementation of extra classes in the Smart Secondary School, Johore done?

2). What is the extent of readiness of teachers in implementing the additional class activities.

3). What is the extent of effectiveness of additional classes conducted in Smart Secondary School, Johore.

\section{Population and Samples}

Population of this study involves all teachers who teach in Smart Secondary School in the state of Johor in 2005 and 2006. This study involves teachers who taught from Form 1 to 5 only. Population is shown in Table 1. The study was conducted in nine secondary schools in the Smart Secondary School at Johor Darul Ta'zim. These schools consist of Day Schools, Boarding Schools and Secondary Religious Schools.

\section{Study Design}

In this study, data collection involving multiple instruments will be gathered using a quantitative questionnaire instrument to enable information to be changed and interpreted meaning of data (Tuckman, 1988) and qualitative data such as that proposed by Patton (1990). Instruments include observation, interviews, checklists and analysis of documents.

Seven major focuses in the questionnaires will be submitted and each section contains items that must be answered by respondents. The focus of the questionnaire is the implementation of additional classes, willingness of teachers, students' acceptance and effectiveness of additional classes. Each questionnaire submitted is believed able to answer the six questions in this study.

There are four items which have been the main focus in observation in this particular study. Researchers will make observations of behavior and no response from the respondents whether remote or with the group of respondents. Aspects of the environment are the classroom observation, teaching and learning aspects of assessment and reference materials used for teaching and learning.

In this study also, researchers will be using a structured interview. A total of seven items have been prepared which is expected to answer three research questions. Responses will be recorded using voice recorder or using a more conventional method of writing. Interview will be either formal or informal. Random samples of layer stacks and random samples are not intended to be used. Interviews will be conducted over ten teachers working in SMK Dato 'Penggawa Barat. Sessions conducted at the time of the interview will be determined after an appointment is made. All question items that are built based on the question of research and verification made by experts who selected the content experts, expert presentations and language experts. Confirmation is made to determine the validity and reliability questions that will be built to include research, presentation patterns and a good use of appropriate language structures.

Researchers also use the checklist form used for recording on whether teachers implement additional classroom activities and evaluate the effectiveness of the additional classes. A total of seven additional class skills are used in the checklist. Five important documents gathered at SMK Dato 'Penggawa Barat will be used as data analysis 
in this study.

In this study, all data and information are obtained and collected are composed of data of high quality. Therefore, researchers need to determine the most appropriate methods to analyze data and information. First, researchers have made in the form of written transcripts of all interview records, record observations and document analysis. Researchers have taken a long time to make copies of the records of interviews, observation notes and document analysis because it requires the researchers' full attention. However, it has been providing opportunities for researchers to familiarize themselves with the data. Once all the data collected has been transcripted, researchers used the coding system which is the main principle in analyzing qualitative data which was designed originally by Marohaini (2001). Fixing the code for each transcript and each segment in the transcript is essential to facilitate the process of referring the original data. The following are examples of coding system that researchers use to coding the interview data (Figure 1), observation data (Figure 2) and report data (Figure 3).

Based on the above coding system, respondents who were interviewed were considered as first respondents, the interview conducted was considered as the first interview. The interview was conducted on $24^{\text {th }}$ October in order to answer the research's study questions .Questions asked were from the first interview questions, and the answer given by respondents were the third sentence from the respondents complete answers for that first interview.

Based on the coding system above, the number of observation done is the first observation, the item observed was the first item, the date of the observation was November 7 and the observation was done in order to answer the first study question.

Once all data and information obtained were categorized according to their codes, researchers make further analysis and assessment of the overall combined data collected through interviews, observation and document review. Analysis is made based on the support by experts or writers of the book related. Once analysis is completed, subsequent researchers have concluded as a whole and determine whether the data obtained answer research questions from the class aspects of the implementation of additional secondary smart schools in Johor, the readiness of teachers in implementing classroom activities and effectiveness of additional classes' additional secondary smart schools in Johor.

\section{Findings and Discussion}

From the study, it was found that almost all studies have shown how students are in dire need of additional classes in order to achieve excellence. Additional class is a session that involves teaching and learning which are conducted after school hours. These classes are allocated to specific students for for revising lessons taught in schools and thus enhancing the quality of students' understanding.

Additional classes are important in encouraging students who are less motivated to learn themselves to attend extra classes. While a student is less desired to understand an educational content, attending extra classes helped these students to gain a better understanding on certain subjects.

Most schools in Malaysia try to apply additional in-class performance to increase school's achievement respectively. They also conduct the classes after school hours or on weekends. However, the school administration cannot be too enthusiastic in pursuing the achievement of high performance in an examination because this matter involves the time and extra commitment from the teachers, who need to divide time for work and for their families. Although the tasks of educating students are the teacher's responsibility, they can only provide and educate based on the formal curriculum. This is because the intention of the Ministry of Education Malaysia's is to produce a successful and excellent student. Therefore, students should not be tackled with a formal education until there is no time for social life such as communication with family, friends and community. Additional classes conducted by schools should be programmed to balance the students' academic and social lives.

However, additional classes often give focus to critical subjects. For example in Smart Schools, they only focused on certain subjects such as Mathematics, Physics, Chemistry and Additional Mathematics. However, different students have different potential. There are students who are skilled in physics but weak in history, but the school does not provide additional classes for history. This brings the effect that students will be versed in physics, but that does not get good results in History. Therefore, additional requirements according to class subjects should be taken into account by the school in ensuring a balance of knowledge. In addition, the balances of teaching excellence to students also bring a balance to the school for each examination.

Studies show the majority of students felt their teachers have have made additional preparations before undergoing the rigorous additional classes. Preparation in teaching is very important in order to produce effective teaching and learning. According to Salihan (2001) between the steps necessary to teach effectively is through 
the rigorous preparation for teaching. Preparatory instruction includes providing teaching aids, teaching planning methods to be used, the objectives of teaching sessions, time slots are allocated, and notes and the required training during teaching sessions.

Teachers who used teaching methods as a whole are at a moderate level. They commonly used methods such as discussion, demonstration methods and methods of study. This finding is similar to the findings of Research Science Department, Pasir Panjang Teaching College where the study results show that the most often method practiced by the trainees during Practicum 1 is the method of group discussion, followed by methods in group activities, role, simulation, storytelling, and project suggestions. Group discussion method was most often used because of the opinion of the trainees' method can trigger the idea of students, involving all pupils, can be managed easily, enjoyable, can share ideas and classes can be controlled.

The teaching method of discussion gained the highest mean between the three types of methods listed by the researchers. This is different from the results of research findings conducted by Johari (1999) of 104 teachers of the implementation of teaching methods when teaching Kemahiran Hidup (Life Skills). This is because the education component and $\mathrm{KH}$ is based on teaching skills (skills), then a more practical method is through demonstrations or demonstrations. According to Esah (2004), it show how useful method in teaching skills for teaching that is centered more to the teachers.

Analysis of the findings also shows high distribution of students' attitudes. This finding overlaps with several other studies which showed students who demonstrate a high commitment and vision have a high subsequent influence that lead to academic achievement. Stressed that the positive attitudes of subjects is required; such attitudes impact on students' motivation. Students who have a 'favourable attitude towards a subject is expected to learn these subjects in greater depth, and will obtained more satisfaction when doing so.

Study findings also found that the level of the distribution of respondents to be the attitude of teachers is at a high level. Research findings from Chiam (1993) showed no impact on the role of teachers' attitudes and students' interest exists where a moderate positive collation. This finding is supported by studies done by Leong Yin Ching, et.al (1990) in collaboration with the Research and Planning Division, Ministry of Education and the World Bank has undertaken a study on primary schools and secondary schools throughout Malaysia. They found that the majority of teachers in schools who achieve high performance seemed to have the perception that their students are very interested in the subjects that they taught).

According to Dembo (1977), teachers are role models to the students, therefore they play an important role in creating an impact in teaching and learning in many aspects, including their behaviour and language usage.

Research findings also show students' high perception towards the effectiveness of extra classes. There is a significant relationship between the effectiveness of additional classes with students' understanding. However, the strength of the relationship is weak. This is consistent with the findings of Gan (2000) where the additional class helped respondents in education, especially in terms of improving and enhancing their decision. Of course the class is labeled effective class of interest and knowledge to provide successful students. However the study has found no significant difference between the effectiveness of the additional classes by gender.

Study findings showed no significant difference between the effectiveness of additional classes with total family income respondents. This is contrary to the findings of Schnabel et. al (2002) which showed that socio-economic status of families is affecting academic achievement of students. Students who are capable of social economic status have higher academic achievement. Schnabel et. al (2002) also found that there are students who earns academic excellence comes from families where the parents have high academic knowledge. These findings support the findings of this study which found that there are significant differences between students' attitudes to the education level of parents of respondents.

Results from data analysis also found a high level of distribution on the respondents' attitudes. Research findings from Chiam (1993) showed no impact on the role of teachers' attitudes and student interest exists when there is a moderate positive correlation. In addition, study results also showed successful teachers make lessons interesting to the respondents of KH subject. Chiam also states that teachers play a vital role in providing motivation and interest to students. Hence, the attitude of students towards Kemahiran Hidup/Life Skills subject was influenced by teachers themselves. Analysis also showed that there is a significant relationship between the effectiveness of additional classes with the understanding of students after attending extra classes. This corresponds with the study of Gan (2000) who found that respondents in extra classes did help, especially in terms of improving education and improving their results. Hence, the performance of respondents in the class also increased after attending the extra classes that are held by the school for them. 
In psychology, when someone is giving more attention to a matter, it will increase the skills of a thing. Similarly, for the extra classes attended by students in which they had learned a lesson previously during school hours, therefore they already have some understanding of a a subject when they attend their extra classes. In addition to the class session, students will be given a simple explanation plus exercises similar to the actual exam. But this process gives the advantage to students who attend extra classes to improve and sharpen their understanding on the subject.

In the process of holding extra classes in school, the parents must be informed in order to know the activities done in school. This is to avoid anxiety to parents. In addition, encouragement and support from parents are important in the success of additional classes held by the school. Openness and encouragement from parents to teacher will motivate the teachers to be more committed in giving lessons to their children. Having the parents' trust is also essential as the schools know that the parents trust the school rather than the tuition centers to educate their children .However, this is sometimes not the case, when there are some parents who send their children to tuition classes as early as Standard 1. This can benefit them as they can gain more knowledge but at the same time it will decrease their aptitude to socialize among their peers. Therefore, parents should have confidence in the schoolteachers' capability in giving adequate preparation in facing examinations.

Based on Azizi, et al, (2006), to test the hypothesis t-test, there is no significant statistical difference between the effectiveness of the additional classes by gender. This shows that gender differences do not affect the effectiveness of different classes of additives. This is because genders, male or female does not affect the effectiveness of additional classes because it depends on the persistence of students themselves. Students either male or female who concentrate on additional classes and use it as a medium to enhance the understanding of an education will get excellent results in examinations. Therefore, gender differences do not bring influence to the effectiveness of additional classes.

Found that there is a significant difference to the effectiveness of additional classes between urban areas and rural areas. Urban areas have a higher level of effectiveness. This is because students in urban schools have more options and access to information resources that facilitate their learning process. Analysis of the study also shows there is a significant difference to the effectiveness of additional classes of stream flow techniques with boarding school. Full effectiveness of boarding schools has a higher flow than technique. Therefore, the results show that extra classes are necessary to improve students' performance as additional knowledge to them apart from learning within formal schooling.

\section{Conclusion}

From the research it is shown that majority of students felt that by attending extra classes it can improve their academic performance. It is also discovered that students' perception towards the effectiveness of extra classes is high. Majority of students felt that teachers had made preparations well before undergoing additional classes. Level of teaching methods used by teachers in extra classes are only at the medium level while teaching method that is widely used by teachers' additional method is the method followed by discussion and lecture demonstrations. Teachers' attitudes and students' attitudes towards extra classes is mainly positive.

Extra classes or tuition are not there to teach students any new knowledge, but more towards revising what has been learned in school. Additional classes can help students in lessons, especially in terms of improving and enhancing their decision. Most students think that their performance in class increases after attending additional classes conducted by the school for them. Teachers are role models for students' learning. Teachers also play an important role to produce the effects of teaching to include students in terms of behavior and language use by teachers. Hence, additional classes must be upgraded from time to time to enhance the progress of students in school.

\section{References}

Abd. Ghafar. (2003). Prinsip dan Amalan Pengajaran. Kuala Lumpur: Utusan Publications \& Utusan Publications \& Distributors Sdn. Bhd.

Arshad, M. (2004). Tuisyen- Amalan Dalam Sistem Pendidikan. Utusan Malaya.

Azizi, Y. Jamaludian, R. \& dan Yusof, B. (2006). Sumbangan Sikap Terhadap Pencapaian Pelajar Dalam Mata Pelajaran Matemtik: Sejauhmanakah Hubungan ini Relevan? Universiti Teknologi Malaysia.

Chiam, Min Kiew. (1993). Sikap Pelajar Tingkatan Tiga Terhadap Pelajaran Kemahiran Hidup. Universiti Teknologi Malaysia: Thesis

Clark, C.M. \& Yinger, R.J. (1987). Teacher Planning. Dalam James Calderhead (Ed.). Exploring Teachers' 
Thinking. London: Cassell Educational Limited.

Dembo, M.H. (1977). Teaching For Learning: Applying Educational Psychology In The Classroom. California: Goodyear Publishing Company, Inc.

Esah, S. (2004). Modul Pengajaran: Asas Pedagogi. Skudai: Universiti Teknologi Malaysia.

Farrant, J.S. (1981). Prinsip dan Amali Pendidikan. Kuala Lumpur: Dewan Bahasa dan Pustaka.

Gan, Chin Guan. (2000). Kajian Mengenai Pandangan Pelajar Tingkatan Empat Terhadap Keberkesanan Kelas Tambahan. Skudai:Universiti Teknologi Malaysia.

Jaafar, S. Maimunah, M.T. Ruziaton, J. \& Lukman, M. (2008). Keberkesanan Kelas Bimbingan Intensif Dalam Meningkatkan Prestasi UPSR di bawah Projek Sekolah.

Johari, A.A. (1999). Pelaksanaan Kaedah-Kaedah Pengajaran Mata Pelajaran Kemahiran Hidup Bersepadu Bagi Guru-Guru Kemahiran Hidup Sekolah Menengah Daerah Gombak. UTM: Projek Sarjana Muda.

Mahzan, A. (2004). Tuisyen- Amalan Dalam Sistem Pendidikan. Utusan Malaysia: 26 January 2004.

Marohaini, Y. (2001). Pengkajian Kualitatif: Pengalaman Kerja Lapangan Kajian: Kuala Lumpur: Universiti Malaya.

Noorwati, S and Zaharah, M. (2003). Kelas Tambahan Guna Kupon. Berita Harian, 17 June, 2003.

Orlich, D.C., Harder, R.J., Callahan, R.C. \& Gibson, H.W. (2001). Teaching Strategies. 6th Edition. New York: Houghton Mifflin Company.

Patton, M.Q. (1990). Qualitative Evaluation and Research Methods (2nd. Ed). Newbury Park: Saga Publications.

Rosli, M. (2002). Teknologi Sebagai Pengupaya Dalam Pelaksanaan Sekolah Bestari dan Pengurusan Pembelajaran Bestari. Jurnal Akademik. Jilid 9. Kota Baru: Maktab Perguruan Kota Baru.

Salihan, S. (2001). Strategi Mengajar Sains Sekolah Rendah. Konvensyen Pendidikan Sains dan Matematik Sekolah Rendah Luar Bandar, Negeri Sembilan.

Salleh, N. \& Manan, Z. Kelas Tambahan Guna Kupon. Berita Harian.

Schnabel, K.U., Alfred, C., Eccles, J.S., koller, O. \& Dan Baumert, J. (2002). Parental Influence on Students' Educational Choices in The United States and Germany: Different Ramifications- Same Effect? Journal of Vocational Behaviour.

Stephens, P. \& Crawley, T. (1994). Becoming an Effective Teacher. England: Stanley Thornes (Publishers) Ltd. Tuckman, B.W. (1988). Conducting Educational Research ( ${ }^{\text {rd }}$. ed). San Diago: Harccourt Brace Javanorich.

Table 1. School's Name, Category and Study Population

\begin{tabular}{|l|l|l|l|}
\hline No. & School & Category & $\begin{array}{l}\text { Total of } \\
\text { Teachers }\end{array}$ \\
\hline 1 & SMK Dato' Penggawa Barat, Pontian & Day School & 98 \\
\hline 2 & SMK (P) Temenggong Ibrahim, Batu Pahat & Day School & 88 \\
\hline 3 & SMK Tun Habab, Kota Tinggi & Day School & 71 \\
\hline 4 & SMK Dato' Sri Amar Diraja, Muar & Day School & 92 \\
\hline 5 & SMK Sains Muar, Tanjung Agas, Muar & Boarding School & 65 \\
\hline 6 & SMK Sains Johor, Kluang & Boarding School & 58 \\
\hline 7 & Sekolah Tun Fatimah, Johor Bahru & Boarding School & 64 \\
\hline 8 & SM Sains Kota Tinggi, Kota Tinggi & Boarding School & 61 \\
\hline 9 & SM Agama Segamat, Segamat & $\begin{array}{l}\text { Religious secondary } \\
\text { school }\end{array}$ & 53 \\
\hline
\end{tabular}

Source: Johore State Education Department (2004) 


\section{[R1T1-24/10(SK1:S1B3)]}

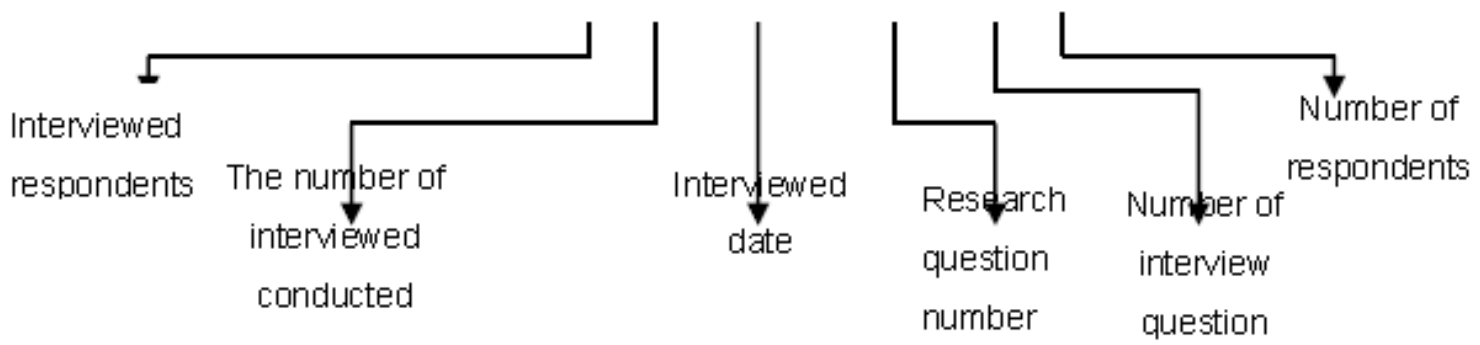

Figure 1. Example of Interview Data Coding System

\section{(P1Bl-7/11:SKl)}

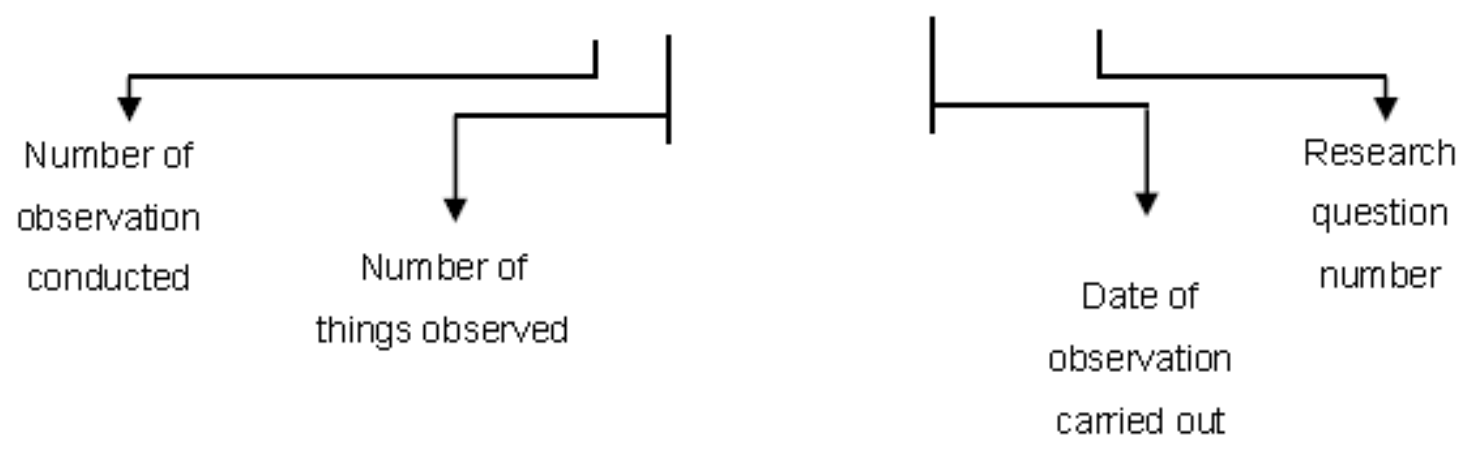

Figure 2. Example of System Data Coding Observation

\section{(SDlBl:SKl)}

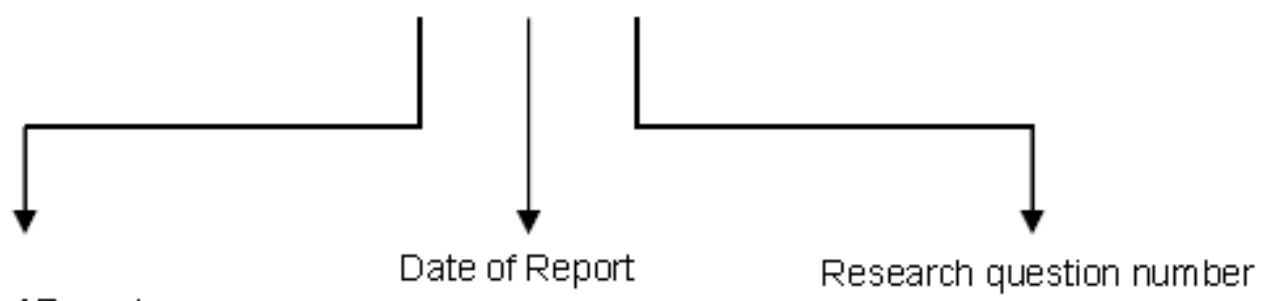

Number of Report

Figure 3. Example of Coding System Report 